\title{
Biological role and health benefits of antioxidant compounds in cereals
}

\author{
Vadim Polonskiy ${ }^{1,2}$, Igor Loskutov ${ }^{3}$, and Alena Sumina ${ }^{4}$ \\ ${ }^{1}$ Department of Landscape Architecture, Botany and Agroecology, \\ Krasnoyarsk State Agricultural University, pr. Mira, 90, Krasnoyarsk, 660049, \\ Russian Federation \\ ${ }^{2}$ Siberian Federal University, Svobodnyj pr., 79, Krasnoyarsk, 660041, Russian Federation \\ ${ }^{3}$ Federal Research Center N. I. Vavilov All-Russian Institute of Plant Genetic Resources, \\ Bol'shaya Morskaya ul., 42-44, Saint Petersburg, 190000, Russian Federation \\ ${ }^{4}$ Department of Geography and Geoecology, N. V. Katanov Khakass State University, \\ ul. Lenina, 90, Abakan, 655000, Russian Federation
}

Address correspondence and requests for materials to Igor Loskutov, i.loskutov@vir.nw.ru

\begin{abstract}
Substances inhibiting or preventing oxidative damage in the target molecule are called antioxidants. It has been shown that antioxidants are substances that contribute to the prevention of a number of serious human diseases, and antioxidant activity is one of the important parameters for the quality of food products and ingredients. Phenolic compounds are of greatest importance for this review. It is now established that whole grain cereals contain a large number of bound polyphenols. It is known that cereals have high nutritional value, contain unsaturated fatty acids, basic mineral elements, proteins and $\beta$-glucans, and are also characterized by the presence of various chemical substances with antioxidant properties. In recent years, work has begun in some Western countries to study the content of antioxidants in various grains. In Russia, only a small amount of work has been devoted to the study of these important chemical compounds in grain crops. It should be noted that, although these species are considered to be one of the main components of human nutrition, research in the field of determining their antioxidant activity has not been sufficiently carried out. In order to attract the attention of plant growers, plant breeders, plant physiologists, geneticists and biotechnologists, we offer a review of current literature.
\end{abstract}

Keywords: grain, wheat, barley, oats, rye, corn, rice, antioxidants, flavonoids, phenolic acids, health, genotype, environmental condition, breeding.

benefits of antioxidant compounds in

doi.org/10.21638/spbu03.2020.105

Author's information: Vadim Polonskiy, Dr. of Sci. in Biology, Professor, orcid. org/0000-0002-7183-0912; Igor Loskutov, Dr. of Sci. in Biology, Chief Researcher, orcid. org/0000-0002-9250-7225; Alena Sumina, $\mathrm{PhD}$, Assistant Professor, orcid.org/00000002-0466-6833

Manuscript Editor: Farida Minibayeva, Laboratory of Redox Metabolism, Kazan Institute of Biochemistry and Biophysics, Kazan Scientific Center, Russian Academy of Sciences, Kazan, Russia

Received: August 2, 2019;

Revised: October 21, 2019;

Accepted: December 11, 2019;

Copyright: (c) 2020 Polonskiy et al. This is an open-access article distributed under the terms of the License Agreement with Saint Petersburg State University, which permits

to the authors unrestricted distribution, and self-archiving free of charge.

Funding: This research was carried out the framework of the state assignment № 06622019-0006.

Competing interests: The authors have declared that no competing interests exist.
The problem of 'healthy' nutrition has been scrutinized in Russia since the 1920s. Nikolai Vavilov, while building up his famous collection of cultivated plants, as early as 1922 started the deployment of a laboratory of plant biochemistry and technological assessment, which boasted the most up-to-date equipment in those days because of his efforts. In addition to complex biochemical analysis of plant germplasm accessions, the laboratory studied vitamins and other substances of secondary origin, now known as bioactive compounds (BAC). Those investigations resulted in eight published volumes of Biochemistry of Cultivated Plants, dedicated to separate groups of crops (Konarev, 1994; Loskutov, 1999; Loskutov, 2009). During the entire period of the laboratory's existence (currently reorganized into the Department of Biochemistry and Molecular Biology), it managed to examine tens of thousands of accessions representing the world's plant genetic diversity, including the voluminous stock of plant breeding materials. The results of such an enormous amount of work have been presented in numerous catalogues, databases, guidelines, journal articles, and monographs (Konarev and Horeva, 2000). Recent years have been marked by the development of a metabo- 
lomic approach, based on the modern chromatographic technique combined with mass spectrometry. This approach enables researchers to identify various plant metabolites, including compounds with increased antioxidant activity. Almost a century of experience comprehensively studying the global plant genetic resources collection founded by Vavilov has demonstrated that the holdings of the Vavilov Institute (VIR) are an inexhaustible source of chemical compounds essential for healthy, dietary and remedial human nutrition (Konarev et al., 2019).

According to the Food Security Doctrine of the Russian Federation, there are plans for the near future to expand the assortment of safe and high-quality food products fit for a healthy diet, including functional ones. This task requires a search for relevant food sources. Antioxidants are among the substances that may prevent a number of serious human diseases, while antioxidant activity is one of the important factors determining the quality of foodstuffs and their ingredients. By now, the overall content of antioxidants and the levels of their activity have been sufficiently measured for vegetable and fruit crops. In recent years, works have been launched around the world to examine the content of antioxidants in the grain of various cereals. In Russia, the study of these important chemical compounds in cereal crops is currently in the beginning phase.

\section{The content and properties of plant antioxidants}

Substances inhibiting or preventing oxidative damage in the target molecule are called antioxidants (Halliwell, 2007). They facilitate the removal of free radicals through autoxidation, thus stopping chain reactions (Shebis et al., 2013). There are two main groups of antioxidants in live cells: enzymatic and non-enzymatic. The latter group is subdivided into several subgroups, the major of which are vitamins (A, E, C), enzyme cofactors (Q10), minerals (zinc and selenium), peptides (glutathione), phenolic acids as well as polyphenols, sulfur compounds, lignin and phytic acid (Fardet, 2010; Shebis et al., 2013).

Flavonoids are the most powerful natural anioxidants, while vitamins $\mathrm{E}$ and $\mathrm{C}$ and carotenoids are weaker (Yashin et al., 2012). A precise chromatographic analysis has shown the presence of different carotenoids in plants, such as lutein and zeaxanthin (Masisi et al., 2015), as well as vitamin E. There are eight presently known natural isoforms of vitamin $\mathrm{E}: \alpha-, \beta-, \gamma$ - and $\delta$-tocopherols, and $\alpha-, \beta-, \gamma-$ and $\delta$-tocotrienols. Different fractions of the cereal crop grain contain an extensive chemical diversity of flavonoids (Pihlava et al., 2018). Phenolic compounds, along with flavonoids, are powerful antioxidants. Phenols are products of secondary synthesis, characterized by the presence of at least one aromatic ring with one or more hydroxyl groups, forming bonds from simple molecules to complex highmolecular polymers, and are divided into a number of subclasses: phenolic acids, flavonoids, coumarins and tannins (Multari et al., 2018).

Phenolic compounds in plants either exist in free form or are bound to cell walls. Only a small number of phenolic acids are found in free form (Pang et al., 2018; Adom and Liu, 2002; Liu, 2007; Yoshida et al., 2010). Bound antioxidants are linked with lignin, polysaccharides and proteins (Madhujith et al., 2006; Cai et al., 2015). The basic phenolic compounds in the main cereal crop species are ferulic, sinapic, caffeic and coumaric acids (Adom and Liu, 2002; Hosseinian and Mazza, 2009; Li et al., 2010; Gawlik-Dziki et al., 2012; Das and Singh, 2015; Zhu et al., 2015; Trehan et al., 2018). The analysis of wheat, barley, rye, oat, millet, rice, maize and sorghum grains has identified benzoic acid derivatives (gallic, salisylic, vanillic, syringic, protocatechuic and hydroxybenzoic acids) (Dykes and Rooney, 2007). Ferulic acid exists in free, conjugated and bound forms at a ratio of 0.1:1:100 (Adom and Liu, 2002), while sinapic acid is found mostly in conjugated form (Nicoletti et al., 2013). Bound fractions of the compounds in question make a decisive contribution to the grain's antioxidant activity: $90 \%$ in wheat, $87 \%$ in maize, $71 \%$ in rice, and $58 \%$ in oats (Adom and Liu, 2002). The total antioxidant activity of grain fractions is an effect of various phenolic compounds (Fardet et al., 2008; Chen et al., 2018). It has been shown that in cereal crops the total content of those compounds in grain correlates well with the level of antioxidant activity (Zhou et al., 2004; Yao et al., 2010; Kaur et al., 2017; Chen et al., 2018; Shao et al., 2018).

Natural antioxidants are naturally originated aggregates of hydrophilic and hydrophobic metabolites, participating, as a rule, in defensive responses of cells to unfavorable abiotic factors and diseases. One illustration of this is that the oxidative stress caused by accumulation of reactive oxygen species leads to an increase in the concentration of antioxidants in plants (Wang and Frei, 2011; Gordeeva et al., 2018). For example, droughtresistant durum wheat cultivars manifested higher levels of phenols in their leaves under drought conditions than susceptible genotypes. The content of phenolic compounds in maturing kernels of drought-resistant cultivars was much higher under stressor conditions than in control conditions (Shoeva et al., 2017; Liu et al., 2018). Besides, antioxidant activity correlates with the resistance of plants to Fusarium pathogens and heavy metal ions (Shoeva and Khlestkina, 2018; Loskutov et al., 2019a).

Cereal crops are the most widespread type of plantderived food, and the interest in their antioxidant properties as a source of food product enrichment is quite understandable. To date, in Russia there have been 
limited research efforts aimed at the antioxidant activity of the above-mentioned vital chemical compounds in cereals, so the results of such studies are described in a comparatively small number of publications (Yashin et al., 2012; Loskutov et al., 2016; 2019b; Polonskiy et al., 2016a; Khlestkina et al., 2017; Usenko et al., 2018; Konarev et al., 2019).

\section{The role of antioxidants in human health preservation}

The well-known free radical theory of ageing, in its essence, states that chronic conditions in a human organism are provoked by free radical damage over its lifetime. It leads to an increased risk of serious diseases and disabilities (Gupta and Prakash, 2015). Highly active free radicals are able to disrupt links within a DNA molecule or damage the genetic apparatus of cells which regulates their growth, thus causing oncological diseases.

A protective tool against the activity of free radicals is the natural antioxidant system, containing enzymatic and non-enzymatic substances that neutralize the harmful effect of reactive oxygen species (Yashin, 2008). It has been found that an oxidant addressed in the mitochondrion may serve as the inhibitor for the process of slow poisoning of an organism with reactive oxygen species. Today, such a substance under the name of SkQ1 has been synthesized on the basis of the antioxidants plastoquinone and decyltriphenylphosphonium. It has been shown that this compound can prolong the lifespan of various organisms: fungi, plants, invertebrates, fish and mammals, and may be used to treat animals for a number of age-related ailments (Skulachev and Skulachev, 2017).

There is proof for the postulation that an increase in consumption of various phenolic compounds contained in food products can reduce the risk of health problems because of their antioxidant activity (Shahidi and Ambigaipalan, 2015). More than two thousand years ago the famous Hippocrates said: "Let food be thy medicine...," and it has never been truer than today. Indeed, in recent years the interest in alimentary antioxidants as tools to prevent a number of serious human diseases has obviously increased (Hurtado-Fernández et al., 2010).

Cardiovascular diseases are known to be the predominant cause of death in industrially developed countries. An initiating event in the case of atherosclerosis or induration of the arteries is oxidation of low-density lipoproteins. These aggregates are often deposited on vascular walls, entailing aggravation of cardiovascular disorders. By now, the processes of binding antioxidant polyphenols with low-density lipoproteins and serum albumin have been adequately studied (Poloni et al., 2019).

Differences in the antioxidant capabilities of various cereal crops have been experimentally proven to influ- ence the antioxidant status of their consumers (Zduńczyk et al., 2006). For instance, it was shown that bound forms of barley grain phenols contribute much to the antioxidative and antiproliferative activity against cancer cells in the human liver (HepG2). The high concentration of these bioactive compounds in barley may be responsible for its usefulness in controlling widespread diseases, including cancer, cardiovascular disorders, diabetes and obesity (Zhu et al., 2015; Idehen et al., 2017).

Oat is characterized by the presence of a whole series of components with increased antioxidant activity, including such unique chemical compounds as avenanthramides (Loskutov, 2007; Martinez-Villaluenga and Penas, 2017; Chen et al., 2018; Leonova et al., 2019). The content of these compounds in different oat products varies from 9.2 to $61.8 \mathrm{mg} / \mathrm{kg}$ (Wu et al., 2018) or within the range of $2-82 \mu \mathrm{g} / \mathrm{g}$, respectively calculated for wet or dry weights. Mean consumption of avenanthramides with food by the population varies from 0.3 to $2.1 \mathrm{mg} /$ day, which is considerably less than the amount used to analyze the biological effects of avenanthramides on humans (Pridal et al., 2018). Experiments with rats have shown that it is possible to maintain a higher level of these antioxidants in their organism by repeated feedings (Koenig et al., 2011). Clinical trials on people have confirmed that an oat grain with avenanthramides possesses antiphlogistic, antiallergic and antioxidative properties, reducing the expression of ischemic heart disease (Gao et al., 2015). It has become evident by employing oat cultivars in a study that grain phenols affect the digestibility of starch and transport of glucose in the intestines, and may serve as a modulator of glycemic response in food products (Li et al., 2017). Fatty acid content and nutritive value have been analyzed in naked oat cultivars. The results have proven that the tested cultivars may be regarded as useful sources of valuable oil, which plays an important role in preventing cardiovascular diseases (Kouřimská et al., 2018). It should be additionally mentioned that oat and barley grains demonstrate high contents of not only antioxidant compounds but also low-molecular $\beta$-glucans (Loskutov and Rines, 2011; Loskutov and Polonskiy, 2017). The latter can serve as natural antioxidants and, as shown in experiments with healthy rats, function synergistically with soluble antioxidants, thus reducing peroxidation of lipids in animal blood plasma (Du and $\mathrm{Xu}, 2014$; Suchecka et al., 2015). By now, however, the physiological significance of oat antioxidants has not yet been studied thoroughly enough (Liu, 2010).

The research on the antioxidative potential of cereal crops involved various underutilized crops-rye, spelt, primitive and wild wheat. It appeared that a majority of these cereal crops revealed higher antioxidative properties in human cell culture than conventional wheat cultivars (Akkoc et al., 2019). 
Whole-grain groats of cereal crops are a good source of many antioxidants, having a high antioxidative potential in vitro: vitamin E, folic acid, phenolic compounds, carotenoids, phytic acid, zinc, iron and selenium (Adom and Liu, 2002; Fardet, 2010; Xu et al., 2016; Liu et al., 2018). The whole grain of wheat or barley is known to be a rich source of bioactive phytochemical compounds, such as phenolic acids, carotenoids, tocopherols, flavonoids, alkylresorcinols, phytosterols and lignans (Luthria et al., 2015). Wheat and barley grain samples have shown strong anti-inflammatory and antiproliferative potentials. Whole-wheat flour extracts were found to inhibit the proliferation of the HT-29 adenocarcinoma cell line (Idehen et al., 2017). It was established that inclusion of whole-grain bread in the diet lessened the risk of a heart attack. The authors assumed that cereal crops, especially rye and oats, may have a beneficial effect on human health (Helnas et al., 2016).

The whole grain of cereals exposes its antioxidative properties in many respects due to the relative abundance of such bioactive compounds in hull and bran fractions (Luithui et al., 2019). The results of the research on oat cultivars showed that in most cases antiproliferative abilities of oat bran were higher than in corresponding whole oat grain samples (Chen et al., 2018). Measuring the antioxidant activity of phenolic extracts from rye whole grain, bran and flour has distinguished rye bran as a source of alimentary phenolic antioxidants, which may potentially bring about positive aftereffects for human health (Andreasen et al., 2001). Consumption of oat bran with an increased level of avenanthramides has been shown to decrease damage in the aorta and produce an obviously beneficial effect upon cardiovascular disease prevention (Thomas et al., 2018). There are publications describing experimental testing of hypotensive and hypoglycemic properties of the bran produced from rice, wheat, oat, barley, sorghum, millet, rye and maze grain. It has been shown in the outcome that bran can reduce oxidative stress, prevent the risk of obesity, and alleviate cardiovascular complications (Patel, 2015). Thus, grain bran has become important for enrichment of food with antioxidants while developing functional ingredients with high nutritive value and useful properties for health improvement (Chinma et al., 2015; Das and Singh, 2015; Patel, 2015).

The benefits of cereal crops for human health are known to depend not only on the activity of antioxidant compounds in them, but also on the biological accessibility of the latter in various tissues, the functions of their metabolites in an organism, the effectiveness of their absorption and in vivo utilization by the gastrointestinal tract (Masisi et al., 2016). General bioaccessibility of grain polyphenols is reported to comply with the following sequence: chickpea $>$ wheat $>$ sorghum (Hithamani and Srinivasan, 2014). Evidence has been demonstrated that enriching bread with compounds contained in the aleurone layer can increase the bioaccessibility of ferulic acid - an antioxidant impeding the development of cancers and Alzheimer's disease (Bresciani et al., 2016). Laboratory tests have been performed to assess the bioaccessibility of thiamine, niacin and phenolic acids obtained from various aleurone fractions of durum wheat cultivars. The results have shown that the bioaccessibility of basic phenolic compounds and the studied vitamins is higher in the inner part of the aleurone layer than in its outer part or in unfractionated bran (Zaupa et al., 2014). The data of the research carried out in vitro, in vivo and on humans have demonstrated that phenolic compounds possess powerful antioxidant properties (Shi et al., 2014).

In addition to the abovementioned phenolic compounds, excellent antioxidant, antiphlogistic and neuroprotective properties are found in some isoforms of the natural vitamin E, specifically tocotrienols (Sen et al., 2007; Peh et al., 2016). The results have shown that tocotrienols, present in such products as rice bran and other cereals, are among the most promising compounds for cancer prevention (Miyazawa et al., 2011). Quercetin is one of the most widespread and strongest antioxidants in nature. It is characterized by numerous biological effects, including antithrombotic activity (Branković et al., 2015). Colored grain is a rich source of anthocyanins, which are capable of playing an important role in preventing various diseases associated with oxidative stress. Considering the omnipresent distribution of cereal crops, their anthocyanin-rich colored grains may be used as a functional food ingredient, advantageous in securing the health of a considerable part of the world's population (Žilić et al., 2019). Experiments were performed with maize, where anthocyanin-rich forms with violet or red kernels showed a potential ability to inhibit the proliferation of human large intestine cancer cells by contributing to the process of apoptosis (Mazewski et al., 2017).

Today, antioxidants are important components of the most popular active ingredients in functional food products. Since the initial raw materials are not expensive, such products are available to the general public and can compensate for the deficit of bioactive compounds in the diet, enhance the resistance of an organism to unfavorable environmental stressors, and thereby extend the lifespan of the population.

\section{Antioxidant content in grain and bran of various cereal crops}

Among cereal crops, interspecific differences have been found in the aggregate content of antioxidants, specifically phenolic compounds as well as carotenoids and tocopherols. They manifested themselves when chemical extracts obtained from whole-grain oat, rye, barley, 
maize, triticale, durum wheat and bread wheat were studied (Adom and Liu, 2002; Menga et al., 2010; Žilić et al., 2011). In their level of antioxidant activity, the cereal crop species were ranked in descending order as follows: naked barley, rye, naked oat, durum wheat, and bread wheat (Zieliński and Kozłowska, 2000; Ragaee et al., 2006; Zduńczyk et al., 2006; Žilić et al., 2011; Tufan et al., 2013).

Wheat samples were found to contain four tocols ( $\beta$-tocotrienol, $\alpha$-tocotrienol, $\beta$-tocopherol and $\alpha$-tocopherol), while the grain of spring barley demonstrated the highest content of $\alpha$-tocotrienol (Lachman et al., 2018). Cereal crops and their fractions (barley, covered oat and dehulled oat, oat bran, and triticale) were studied in vitro for the content of polyphenols and a-tocopherol and for their total antioxidant efficacy; among the studied cereals, the highest antioxidant activity was observed in barley, and the lowest in dehulled oat (Zduńczyk et al., 2006). The tocotrienol, tocol and lutein contents appeared to be higher in the whole grain of einkorn wheat (Triticum monococcum) than in common wheat (Hidalgo et al., 2009). After comparing the content of carotenoids in wheat samples with different grain colors, the lowest carotenoid content was registered in cultivars with blue kernels, while those with violet kernels had the same level as common wheat or higher. Lutein was the main carotenoid in wheat, and zeaxanthin dominated in barley samples (Paznocht et al., 2018). The barley genotypes were analyzed for the content of tocols and of free and bound phenolics. Total tocol content in barley samples varied from 39.9 to $81.6 \mu \mathrm{g} / \mathrm{g}$. In total, barley contained 64 compounds, including 19 phenolic acids and aldehydes, 9 flavonoid glycosides and 27 anthocyanins (Martínez et al, 2004).

Alkylresorcinols (antioxidants) were present in wheat $(489-1429 \mu \mathrm{g} / \mathrm{g})$, rye $(720-761 \mu \mathrm{g} / \mathrm{g})$, triticale $(439-647 \mu \mathrm{g} / \mathrm{g})$ and barley $(42-51 \mu \mathrm{g} / \mathrm{g})$, but absent in rice, oats, maize, sorghum and millet (Ross et al., 2003). In another work the content of alkylresorcinols and phenolic acids was analyzed in products of cereal crop species. The highest content of phenolic acids was registered in the bran of wheat $(4527 \mathrm{mg} / \mathrm{kg})$ and rye $(4190 \mathrm{mg} / \mathrm{kg})$, and in the whole-grain flours of these species (1342 and $1366 \mathrm{mg} / \mathrm{kg}$, respectively) (Mattila et al., 2005).

Experiments with wheat, oat, rice and maize showed that maize had the highest content of phenolics (15.6 $\mu \mathrm{mol}$ of gallic acid equiv/g of grain) and manifested the highest total antioxidant activity $(181.4 \mu \mathrm{mol}$ of vitamin C equiv/g of grain), followed by wheat (76.7), oat (74.7) and rice (55.8) (Adom and Liu, 2002). Lutein, vitamin $\mathrm{E}$ and alkylresorcinols were quantitatively assessed in the whole-grain flour of 15 wheat cultivars that belonged to five different species grown in four different areas. Einkorn wheat was found to have the highest level of lipophilic antioxidants (Ziegler et al., 2016).
Rye grain is known to be a rich source of various antioxidants, including phenolic acids, lignans and alkylresorcinols (Pihlava et al., 2018). It was shown on bread samples prepared from different rye cultivars that their antioxidant activity depended on the unique profile of anthocyanins, phenolics and other compounds in each genotype (Zieliński et al., 2007; Lopez-Martinez et al., 2009). High contents of ferulic acid and three important flavonoids, together with significant antioxidant activity, were registered in the grain of maize. This crop may be regarded as a potential source of antioxidants in functional food products (Adom and Liu, 2002; Žilić et al., 2011; Guo and Beta, 2013; Das and Singh, 2015).

Chemical compounds possessing antioxidant activity are unevenly distributed within the kernel. This is confirmed by the results of numerous analyses (Zhou et al., 2004). In one of such works kernels of naked barley cultivars were cut into five layers to measure the total content of soluble phenolic compounds and total antioxidant activity. The total content of soluble phenolics was found to decline from the outer layer to the inner structures of the endosperm (Gong et al., 2012; Ndolo et al., 2013). Antioxidant activity was assessed in different fractions of the milled grain of durum and bread wheat cultivars. It appeared that with the rising of the milling degree this activity considerably decreased, and the highest antioxidant activity was registered in the 10-20\% milling fraction (Liyana-Pathirana et al., 2006). The grain of covered barley cultivars was gradually dehulled, and $5 \%$ of its weight was removed with each of the eight processing cycles. The total antioxidant activity reached its maximum in the $15-25 \%$ mass fraction of grain (Blandino et al., 2015). The barley genotypes were studied for the content of tocols in different milling fractions. The results showed that the highest content of these antioxidants was in the $5-10 \%$ mass fraction (Badea et al., 2018). The barley cultivars were divided into seven fractions and then extracted with $80 \%$ methanol. For both cultivars, the maximum content of phenols was found in the most external fraction (Madhujith et al., 2006). Similar results were obtained for wheat cultivars (Sovrani et al., 2012).

Studies on wheat bran and flour found that the bran fraction contained much higher concentrations of various antioxidants (Liyana-Pathirana and Shahidi, 2007; Žilić et al., 2011). The results of experiments that involved cultivars of wheat and barley demonstrated that for all genotypes the antioxidant activity level in the bran fraction was 3-5 times higher than the corresponding one in the flour fraction (Siebenhandl et al., 2007). The cultivars of winter rye were employed to show that the content of antioxidants in bran was higher than in flour (Goncharenko and Timoshenko, 2014).

Kernels of barley samples grown for three years were analyzed for the total content of folic acid. The 
outer layers and those containing the germ demonstrated its highest content (Edelmann et al., 2012, 2013). The research performed on barley cultivars showed that the total content of phenols and antioxidant activity were higher in the outer bran fractions. However, the distribution of individual polyphenols and lipophilic compounds varied within the kernel; for example, ferulic acid and procyanidin were not found in the flour fraction (Gangopadhyay et al., 2018). Phenolics were extracted from barley hulls obtained in the process of milling. The content of p-coumaric and ferulic acids appeared to be high, which confirms the high value of barley hull as a source of natural antioxidants (Hajji et al., 2018). It was shown that the amount of phenolic acids in the grain of covered and naked barleys varied, and higher levels of these compounds were observed in hulls (Holtekjølen et al., 2006).

The bran of rice, wheat, oat, barley, sorghum, millet, rye and maize contained phenolic acids (ferulic acid), flavonoids (anthocyanins), vitamins (carotenoids and tocols), folates and other compounds (Guo and Beta, 2013; Patel, 2015). Preparations isolated from rye bran manifested higher antioxidant activity, despite the lower total level of polyphenols (Rosicka-Kaczmarek et al., 2018).

Other research proved that a majority of antioxidants in the grain composition were contained in bran and the kernel germ fraction. For example, in wholegrain flour, germ fraction and bran there were $83 \%$ of phenolics and $79 \%$ of flavonoids (from their total content), $78 \%$ of the total zeaxanthin and $51 \%$ of the aggregate lutein (Liu, 2007). In research on durum wheat the highest content of phenols was registered in coarse bran (Nicoletti et al., 2013). The case study of barley, oat, wheat and maize demonstrated that the antioxidant activity of carotenoids in the aleurone fraction was $50 \%$ of that in the germ fraction (Ndolo et al., 2013). For several samples of wheat bran, the equivalent antioxidant capacity was identified in decreasing order: wheat bran powder $\geq$ wheat bran with malt flavor $\geq$ wheat bran alone $\geq$ bran breakfast cereal $>$ tablet of bran $>$ tablet of bran with cellulose (Martínez-Tomé et al., 2004).

Since phenolics concentrate in outer layers, bran obtained from grain processing may be used as a natural source of antioxidants and as a value-adding product for functional food ingredient production (Liyana-Pathirana et al., 2006). Today, cereal bran, a by-product of grain processing, has won a crucial status in functional food recipes. It has been recognized as a reservoir of nonstarch carbohydrates (arabinoxylan and $\beta$-glucan), phenolic acids (ferulic acid), flavonoids (anthocyanin), oils ( $\gamma$-oryzanol), vitamins (carotenoids and tocols), oligosaccharides and sterols (Patel, 2015). It should be mentioned, however, that there are publications testifying to a high content of antioxidants in the aleurone layer of wheat grain, meaning, for the most part, a relatively large amount of phenolics, first of all of ferulic acid, in this fraction (Anson et al., 2008); or to a high content of antioxidants in germ fractions of barley, maize and wheat kernels (Masisi et al., 2015).

\section{Dependence of the content of antioxidants in grain on the genotype and cultivation conditions}

The content of antioxidants in the kernel is influenced by the plant genotype and growing conditions. Some authors have concluded that the effect of environments on antioxidant activity is greater than that of the genotype. For example, a majority of oat cultivars manifested higher content of $\alpha$-tocotrienols and higher antioxidant activity when they were cultivated on clay soils (Broeck et al., 2016). In another study, analysis of the content of avenanthramides and the antioxidant activity in oat grain showed that the effect of environments was much higher than the role of the genotypes or interaction between these two factors (Li et al., 2017). The effect of sowing time on the content of antioxidants was studied in the whole-grain flour of colored maize genotypes. Significant influence of environmental conditions was shown for the period of grain formation; with this in view, early-spring sowing could provide advantages for the content of some phenolic acids in maize (Giordano et al., 2018). Application of nitrogen fertilizers for two years to the soil where einkorn wheat was grown increased the content of protein and phenolics in grain. A similar but less obvious effect was observed for the concentration of tocols in grain (Hidalgo and Brandolini, 2017). In order to assess the effects of the genotype, the growing environment, and their interaction on the total content of phenolics in cereal crops, the composition of chemical extracts from whole-grain durum and bread wheat, oat, barley and triticale was analyzed (Menga et al., 2010). In order to disclose the differences between local and advanced cultivars, antioxidant activity and the total content of polyphenols and flavonoids were measured in the grain of durum wheat and bread wheat grown for two years on one and the same plot. The main factor that determined the qualitative profile of polyphenols and the grain's antioxidant activity was the temperature regime during the 30 days before harvesting; for example, high temperatures caused a decline in the content of polyphenols in the grain (Heimler et al., 2010). Wheat and barley were studied to show that high temperatures and drought throughout the growing season were accompanied by more active biosynthesis of carotenoids (Paznocht et al., 2018), while abundant rainfall and lower temperatures contributed to an increased tocol content in most cultivars (Lachman et al., 2018). Comparison was made in rye cultivars between the effects of conventional and organic 
cultivation practices to assess the content of phenolics as well as antioxidant and antihyperglycemic properties using the in vitro model. Rye grown in compliance with organic practices was found to have higher inhibiting activity of $\alpha$-amylase and higher contents of ferulic and benzoic acids (Mishra et al., 2017).

A number of authors have concluded that both the genotype and environmental conditions produce an effect on the content of antioxidants. For example, the content of phenolics in the grain of durum wheat was found to depend mostly on environmental conditions, while the content of yellow pigments and the total antioxidant activity level were essentially influenced by genetic factors (Martinia et al., 2015). The total antioxidant capacity of barley and oat grain was subject to the effect of both environmental factors (weather conditions, fertilization, etc.) and the genotype (Polonskiy et al., 2016a; Mareček et al., 2017). To assess the effect of the genotype, year and place of growing on the content of protein, lipids, tocol and lutein in whole-grain flour, samples of einkorn wheat and samples of common wheat were cultivated for two years in four different places in Italy. It appeared that the genotype and the year of cultivation had a significant impact on the contents of protein, tocotrienol and lutein, but the amounts of tocopherol and lipids depended solely on the genotype (Hidalgo et al., 2009). The results procured during two years of durum wheat cultivation showed higher contents of phenols and antioxidant enzymes and higher antioxidant activity in cv. 'Saragolla' than in cv. 'Cappelli. However, the effect of the year of cultivation, which depends to a sizeable extent on different precipitation regimes, was significant for a majority of the analyzed biochemical parameters (Graziano et al., 2019). The soluble fraction of phenolics in various wheat cultivars was found to be mainly determined by the environment, while the major genotypic effect was observed in the bound forms present in great amounts in red-grain cultivars (Di Silvestro et al., 2017). The results of the grain antioxidant activity test involving winter rye cultivars showed that the total antioxidant content varied in different cultivars and under different weather conditions across the years of cultivation (Goncharenko and Timoshchenko, 2014). The effect of the genotype and growing conditions on the content of phenolics and antioxidant activity was analyzed in durum wheat cultivars grown in four different areas of Western Canada. Variability of antioxidant properties in genotypes suggests that it is possible to choose these quantitative characters for a breeding program; however, the observed significant changes caused by the environment can make this process more complicated (Mpofu et al., 2006).

When studying the effect of the genotype and growing conditions on cereal crops, wide variability was found among cultivars in the content of antioxidants in their grain. For example, the content of phenolic acids in spelt grain varied significantly across the tested cultivars within the range from 506.6 to $1257.4 \mu \mathrm{g} / \mathrm{g}$ dry weight (DW). The total content of ferulic acid varied from 144.2 to $691.5 \mu \mathrm{g} / \mathrm{g}$ DW. All analyzed spelt cultivars demonstrated their high antioxidant potential (Gawlik-Dziki et al., 2012). The study of the content of lipophilic antioxidants in bread wheat, durum wheat, spelt and einkorn wheat showed that concentrations of these compounds are determined mainly by genetic factors (Ziegler et al., 2016). The levels of antioxidants (sterols, tocols, avenanthramides, folates and phenolic acids) were measured and their composition was analyzed in the grain of oat cultivars (covered and naked) grown under similar conditions for one year. Tocol, phenolic acid and avenanthramide concentrations were found to have more than twofold variation among the cultivars (Shewry et al., 2008). In another study dedicated to barley antioxidants, cultivars were identified for higher levels of these compounds in grain, which confirmed realistic prospects of such a breeding trend for barley (Andersson et al., 2008). Grain analysis in various barley cultivars grown for three years showed that the total content of folic acid varied across cultivars (Edelmann et al., 2013; Do et al., 2015). By now, oat cultivars have been identified with maximum totals of avenanthramides and phenolic acids in grain (Chen et al., 2018). The analysis of the effect produced by the genotype on phenolic acid biosynthesis in oat kernels demonstrated considerable variation in the contents of ferulic and coumaric acids and in the total amount of phenolics in different oat accessions (Alfieri and Redaelli, 2015). The diversity of maize genotypes in phenolic content and potential bioactivity may serve as a platform for the development of new productive maize genotypes with an obvious nutriceutic potential (Zavala-Lopez et al., 2018). A study was conducted to analyze the content of phenolic acids in the grain of modern commercial and local cultivars of bread wheat. The authors observed significant differences in the profiles of these chemical compounds between modern and local genotypes, the latter showing higher amounts of major phenolic acids (Gotti et al., 2018). The content of free, bound and total phenolics was assessed in the whole-grain flour of durum wheat cultivars, and the ability of the plants to survive water stress was analyzed. Under water deficit, the grain of the stress-resistant genotypes 'Tamaroi' and 'Yawa' demonstrated higher content of phenolic compounds than the reference, while the stress-sensitive genotypes 'Bellaroi' and 'Tjilkuri' showed no significant changes (Liu et al., 2018). Cavallero et al. (2004) studied the effect of the genotype and the place of cultivation on the amount of tocols in covered and naked barley grain and found out that covered barley accumulated higher amounts of these bioactive compounds. It seems that today the grain's antioxidant activity may be increased in barley (Chen et al., 2017). The content of basic lipo- 
philic antioxidants (carotenoids and tocols) in kernels was assessed employing primitive wheat species and cultivated bread wheat to compare their potentials as donors of useful antioxidant properties (Hejtmánková et al., 2010; Lachman et al., 2013). Einkorn wheat demonstrated a sizeable effect produced by the genotype on its carotenoid and tocol levels, which differed from those in emmer and bread wheat. In their research, Shewry and Hey (2015) ascertained that the highest amount of tocotrienols $(74 \%)$ among different wheat species was contained in primitive species. Other authors opined that the noticeable spread of values in the content of tocopherol and tocotrienols among the studied wheat genotypes suggested that there was high potential for future breeding programs to develop definite wheat genotypes with health-enhancing properties (Hussain et al., 2012). However, although the content of carotenoids such as lutein is higher in primitive wheat species than in bread wheat, analyses have failed to confirm that local wheat varieties are generally 'healthier' than modern commercial cultivars (Tucakovic et al., 2015). Genetic analysis of the content of polyphenols and antioxidants made it possible to identify genes and loci controlling quantitative characters responsible for changes in the concentration of polyphenols. Identification of polyphenolic compounds and examination of their genetic bases in different rice cultivars are building the foundation for studying the nutriceutic properties of the whole grain (Shao and Bao, 2015). Besides, work has recently started on barley and wheat to identify genes responsible for biosynthesis of various antioxidants - anthocyanins, flavonoids, melanins, etc. (Strygina et al., 2017; Shoeva et al., 2018; Strygina and Khlestkina, 2019a, b).

\section{Cereal crop breeding for increased content of antioxidants in grain}

When cereal crops are being bred for higher levels of antioxidants in their grain, it is important to analyze and select source material for breeding. Many researchers regard the color of the outer hulls as a handy trait of the grain in the context of predicting its antioxidant activity. For example, a cultivar of barley with violet-colored kernels was reported to contain 11 anthocyanins, while only one anthocyanin was observed in black and yellow barley kernels. The bran of violet-colored barley showed the highest total antioxidant activity (Lee et al., 2013). Other researchers employed naked barley to demonstrate that antioxidant activity in pigmented forms was higher than in colorless ones (Gong et al., 2012). Colored forms of barley (black and blue), when compared with white forms, proved to be a potential source of phenolics and $\beta$-glucans, and possess the highest antioxidant capacity (Lin et al., 2018). The content of anthocyanins and correlations of the total phenolic content with the total antioxidant activity and inhibiting activity of a-glucosidase were studied in pigmented grains of red, violet and black rice, violet maize, black barley and black soybean. Black rice was found to have the highest content of phenolic compounds - 86 times higher than in red rice. In addition, black rice had the highest anthocyanin content and inhibiting activity of $\alpha$-glucosidase (Yao et al., 2010). Measurements were made in the grain of red and white durum wheat genotypes grown in four different locations to assess the concentrations of phenolic acids and antioxidant activity. The highest values of the studied biochemical indicators were recorded in red wheat cultivars, while comparable durum wheat cultivars with white grain demonstrated the lowest levels (Mpofu et al., 2006). Extracts of wheat cultivars were compared to measure their antioxidant properties. The results showed that violet wheat had outstanding antioxidant activity, followed by red wheat and yellow wheat (Liu et al., 2018). The cultivars of red-grain wheat were identified as the most promising source materials for breeding high-value cultivars (Di Silvestro et al., 2017). Purple and blue wheat lines with high amounts of tocols, anthocyanins and phenolic acids in grain may be used for the development of new wheat cultivars, promising for health maintenance and suitable for organic farming (Lachman et al., 2018). It has been shown that blue and violet grains of spring wheat and maize are characterized by an increased content of total anthocyanins and tocols. Nine anthocyanins have been identified in violet-colored wheat, and ten in blue-colored maize (Žilić et al., 2019). The whole grain of maize genotypes differing in color was analyzed for the content of antioxidants. The light-blue genotype of maize contained more total phenols and ferulic acid than the other tested maize genotypes and showed the highest antioxidant activity (Žilić et al., 2012). The content of phenolics and the anthocyanin composition of grain were evaluated in cultivars of purple maze. Anthocyanin profiles were almost identical in different maize samples. Variations were observed only in the relative percentage of each anthocyanin (Montilla et al., 2011). The study of darkhulled and white-hulled covered oat forms showed that the former had credibly higher levels of antioxidant activity (Vargach et al., 2016). Comparison among nearisogenic barley lines differing by the black lemma and pericarp $(B l p)$ gene showed that black-pigmented lines had higher antioxidant activity in their grain. The analysis of lemma and pericarp transcriptomes in those nearisogenic lines identified differentially expressed genes, among which, along with the genes participating in black pigmentation, a gene presumably responsible for antioxidant capacity variations was found (Glagoleva et al., 2017). This gene encodes O-methyltransferase of caffeic acid, which catalyzes transformation of caffeic acid into ferulic acid - a powerful natural antioxidant. 
Further works with near-isogenic barley lines differing by the black pericarp gene have shown that this trait is regulated by one or two genes (Gordeeva et al., 2019).

Grain quality improvement is an important task of plant breeding. Conventional screening techniques used to assess grain quality in cereals are too time-consuming, complicated, damaging, and poorly suited for the process of reproduction. Of high relevance, therefore, are research efforts aimed at the development of new analytical methods and indirect ways of assessing grain quality indicators, which will prove undamaging, simple and rapid. Since the use of chemical means to measure the content of phenolics, flavonoids and antioxidant activity is expensive and laborious, these food quality indicators could be assessed using a rapid and undamaging prognostication technique based on near-infrared spectroscopy (NIRS). Today, gauging models developed to predict the total content of such compounds are suitable for routine screening of large numbers of plant samples in breeding programs (Zhang et al., 2008).

To ensure progress in the breeding of cereal crops for increased antioxidant capacity, one of the requirements is to screen promising cereal cultivars and hybrids for the content of antioxidants in their grain. A number of successful attempts have been made to achieve this goal, and they are described in publications. In barley, for example, a positive correlation was demonstrated between the 1000 grain weight and the concentration of tocols in grain (Andersson et al., 2008), along with a negative correlation between the 1000 grain weight, on the one hand, and the content of ferulic acid and antioxidant activity level in grain, on the other (Goncharenko and Timoshchenko, 2014). Studying different barley cultivars helped to identity positive correlations between the concentration of dietary fibers and the level of phenolics in grain (Andersson et al., 2008) as well as between the filminess of grain and the total content of antioxidants in it (Polonskiy et al., 2016b).

The results of studies involving known cultivars of cereal crops and breeding achievements in the development of new high-yielding and high-quality cultivars rich in antioxidants enable producers to use them for making a wide assortment of functional products, capable of providing a favorable effect on the human organism and contributing to human health improvement.

\section{Conclusion}

The available data confirm the importance of antioxidants, which have a dietary, prophylactic and therapeutic effect on the human body. Physicochemical properties, chemical modifications and manufacturability open up clear prospects for the use of antioxidants in food, drugs and cosmetics, and in these global industries antioxidants will play an increasing role. Thus, the develop- ment of functional foods based on cereal grains involves obtaining high-yielding varieties with the maximum content and optimal chemical structure of antioxidants in combination with other quality indicators. Insufficient knowledge and inconsistency of the available data so far hinder progress in these areas of selection. Therefore, complex studies of the whole variety of cereal crops are necessary in order to isolate contrasting initial forms and create varieties for food and feed use.

\section{Acknowledgement}

This research was carried out the framework of the state assignment № 0662-2019-0006.

\section{Reference}

Adom, K. K. and Liu, R. H. 2002. Antioxidant activity of grains. Journal of Agricultural and Food Chemistry 50(21):61826187. https://doi.org/10.1021/jf0205099

Akkoc, Y., Lyubenova, L., Grausgruber, H., Janovská, D., Yazici, A., Cakmak, I., and Gozuacik, D. 2019. Minor cereals exhibit superior antioxidant effects on human epithelial cells compared to common wheat cultivars. Journal of Cereal Science 85(1):143-152. https://doi.org/10.1016/j. jcs.2018.12.006

Alfieri, M. and Redaelli, R. 2015. Oat phenolic content and total antioxidant capacity during grain development. Journal of Cereal Science 65(9):39-42. https://doi.org/10.1016/j. jcs.2015.05.013

Andersson, A.A.M., Lampi, A.M., Nyström, L., Piironen, V., Li, L., Ward, J. L., Gebruers, K., Courtin, C. M., Delcour, J. A., Boros, D., Fraś, A., Dynkowska, W., Rakszegi, M., Bedő, Z., Shewry, P. R., and Aman, P. 2008. Phytochemical and dietary fiber components in barley varieties in the HEALTHGRAIN diversity screen. Journal of Agricultural and Food Chemistry 56(21):9767-9776. https:// doi.org/10.1021/jf802037f

Andreasen, M. F., Landbo, A.-K., Christensen, L. P., Hansen, Å., and Meyer, A.S. 2001. Antioxidant effects of phenolic rye (Secale cereale L.) extracts, monomeric hydroxycinnamates, and ferulic acid dehydrodimers on human low-density lipoproteins. Journal of Agricultural and Food Chemistry 49(8):4090-4096. https://doi.org/10.1021/ jf0101758

Anson, N. M., van den Berg, R., Havenaar, R., Bust, A., and Haenen, G. R. M. M. 2008. Ferulic acid from aleurone determines the antioxidant potency of wheat grain (Triticum aestivum L.). Journal of Agricultural and Food Chemistry 56(14):5589-5594. https://doi.org/10.1021/jf800445k

Badea, A., Carter, A., Legge, W. G., Swallow, K., Johnston, S. P., and Izydorczyk, M.S. 2018. Tocols and oil content in whole grain, brewer's spent grain, and pearling fractions of malting, feed, and food barley genotypes. Cereal Chemistry 95(6):779-789. https://doi.org/10.1002/ cche.10093

Blandino, M., Locatelli, M., Sovrani, V., Coïsson, J. D., Rolle, L., Travaglia, F., Giacosa, S., Bordiga, M., Scarpino, V., Reyneri, A., and Arlorio, M. 2015. Progressive pearling of barley kernel: Chemical characterization of pearling fractions and effect of their inclusion on the nutritional and technological properties of wheat bread. Journal of $\mathrm{Ag}$ ricultural and Food Chemistry 63(25):5875-5884. https:// doi.org/10.1021/jf506193p

Branković, G., Dragičević, V., Dodig, D., Zorić, M., Knežević, D., Žilić, S., Denčić, S., and Šurlan, G. 2015. Genotype × 
environment interaction for antioxidants and phytic acid contents in bread and durum wheat as influenced by climate. Chilean Journal of Agricultural Research 75(2):139-146. https://doi.org/10.4067/S071858392015000200001

Bresciani, L., Scazzina, F., Leonardi, R., Dall'Aglio, E., Newell, M., Dall'Asta, M., Melegari, C., Ray, S., Brighenti, F., and Del Rio, D. 2016. Bioavailability and metabolism of phenolic compounds from wholegrain wheat and aleurone rich wheat bread. Molecular Nutrition and Food Research 60(11):2343-2354. https://doi.org/10.1002/ mnfr.201600238

Broeck, H. C., Londono, D. M., Timmer, R., Smulders, M. J. M., Gilissen, L. J. W., and Meer, I. M. 2016. Profiling of nutritional and health-related compounds in oat varieties. Foods 5(2):2-11. https://doi.org/10.3390/foods5010002

Cai, S., Han, Z., Huang, Y., Chen, Z.-H., Zhang, G., and Dai, F. 2015. Genetic diversity of individual phenolic acids in barley and their correlation with barley malt quality. Journal of Agricultural and Food Chemistry 63(31):70517057. https://doi.org/10.1021/acs.jafc.5b02960

Cavallero, A., Gianinetti, A., Finocchiaro, F., Delogu, G., and Stanca, A. M. 2004. Tocols in hull-less and hulled barley genotypes grown in contrasting environments. Journal of Cereal Science 39(2):175-180. https://doi.org/10.1016/ S0733-5210(03)00072-9

Chen, J., Liu, C., Shi, B., Chai, Y., Han, N., Zhu, M., and Bian, H. 2017. Overexpression of HvHGGT enhances tocotrienol levels and antioxidant activity in barley. Journal of Agricultural and Food Chemistry 65(25):5181-5187. https:// doi.org/10.1021/acs.jafc.7b00439

Chen, C., Wang, L., Wang, R., Luo, X., Li, Y., Li, J., Li, Y., and Chen, Z. 2018. Phenolic contents, cellular antioxidant activity and antiproliferative capacity of different varieties of oats. Food Chemistry 239(1):260-267. https://doi. org/10.1016/j.foodchem.2017.06.104

Chinma, C. E., Ramakrishnan, Y., Ilowefah, M., Hanis-Syazwani, M., and Muhammad, K. 2015. Properties of cereal brans: A review. Cereal Chemistry 92(1):1-7. https://doi. org/10.1094/CCHEM-10-13-0221-RW

Das, A. K. and Singh, V. 2015. Antioxidative free and bound phenolic constituents in pericarp, germ and endosperm of Indian dent (Zea mays var. indentata) and flint (Zea mays var. indurata) maize. Journal of Functional Foods 13(2):363-374. https://doi.org/10.1016/j.jff.2015.01.012

Do, T.D.T., Cozzolino, D., Muhlhausler, B., Box, A., and Able, A.J. 2015. Antioxidant capacity and vitamin E in barley: Effect of genotype and storage. Food Chemistry 187(15):65-74. https://doi.org/10.1016/j.foodchem.2015.04.028

Du, B. and Xu, B. 2014. Oxygen radical absorbance capacity (ORAC) and ferric reducing antioxidant power (FRAP) of $\beta$-glucans from different sources with various molecular weight. Bioactive Carbohydrates and Dietary Fibre 3(1):1116. https://doi.org/10.1016/j.bcdf.2013.12.001

Di Silvestro, R., Di Loreto, A., Bosi, S., Bregola, V., Marotti, I., Benedettelli, S., Segura-Carretero, A., and Dinelli, G. 2017. Environment and genotype effects on antioxidant properties of organically grown wheat varieties: a 3-year study. Journal of Science of Food Agriculture 97(2):641649. https://doi.org/10.1002/jsfa.7782

Dykes, L. and Rooney, L. W. 2007. Phenolic compounds in cereal grains and their health benefits. Cereal Foods World 32:105-111. https://doi.org/10.1094/CFW-52-3-0105

Edelmann, M., Kariluoto, S., Nyström, L., and Piironen, V. 2012. Folate in oats and its milling fractions. Food Chemistry 135(3):1938-1947. https://doi.org/10.1016/j.foodchem.2012.06.064
Edelmann, M., Kariluoto, S., Nyström, L., and Piironen, V. 2013. Folate in barley grain and fractions. Journal of Cereal Science 58(1):37-44. https://doi.org/10.1016/j. jcs.2013.04.005

Emmons, C. L., Peterson, D. M., and Paul, G. L. 1999. Antioxidant capacity of oat (Avena sativa L.) extracts. 2. In vitro antioxidant activity and contents of phenolic and tocol antioxidants. Journal of Agricultural and Food Chemistry 47(12):4894-4898. https://doi.org/10.1021/jf990530i

Fardet, A. 2010. New hypotheses for the health-protective mechanisms of whole-grain cereals: what is beyond fibre? Nutrition Research Review 23:65-134. https://doi. org/10.1017/S0954422410000041

Fardet, A., Rock, E., and Rémésy, C. 2008. Is the in vitro antioxidant potential of whole-grain cereals and cereal products well reflected in vivo? Journal of Cereal Science 48(2):258-276. https://doi.org/10.1016/j.jcs.2008.01.002

Gangopadhyay, N., Harrison, S. M., Brunton, N. P., HidalgoRuiz, J. L., Gallagher, E., and Rai, D. K. 2018. Brans of the roller-milled barley fractions rich in polyphenols and health-promoting lipophilic molecules. Journal of Cereal Science 83(9):213-221. https://doi.org/10.1016/j. jcs.2018.08.017

Gao, C., Gao, Z., Greenway, F. L., Burton, J. H., Johnson, W. D., Keenan, M. J., Enright, F. M., Martin, R. J., Chu, Y. F., and Zheng, J. 2015. Oat consumption reduced intestinal fat deposition and improved health span in Caenorhabditis elegans model. Nutrition Research 35(6):834-843. https:// doi.org/10.1016/j.nutres.2015.06.007

Gawlik-Dziki, U., Świeca, M., and Dziki, D. 2012. Comparison of phenolic acids profile and antioxidant potential of six varieties of spelt (Triticum spelta L.). Journal of Agricultural and Food Chemistry 60(18):4603-4612. https://doi. org/10.1021/jf3011239

Giordano, D., Beta, T., Gagliardi, F., and Blandino, M. 2018. Influence of agricultural management on phytochemicals of colored corn genotypes (Zea mays L.). Part 2: Sowing time. Journal of Agricultural and Food Chemistry 66(17):4309-4318. https://doi.org/10.1021/acs. jafc. 8 b00326

Glagoleva, A. Y., Shmakov, N. V., Shoeva, O. Y., Vasiliev, G. V., Shatskaya, N. V., Börner, A., Afonnikov, D. A., and Khlestkina, E. K. 2017. Metabolic pathways and genes identified by RNA-seq analysis of barley near-isogenic lines differing by allelic state of the Black lemma and pericarp (B/p) gene. BMC Plant Biology 7(Suppl. 1):182. https://doi. org/10.1186/s12870-017-1124-1

Goncharenko, A. A. and Timoshenko, A. S. 2014. Evaluation of rye cultivar on antioxidant activity of grains. Russian Agricultural Science 4:3-7. (In Russian)

Gong, L. X., Jin, C., Wu, L. J., Wu, X. Q., and Zhang, Y. 2012. Tibetan hull-less Barley (Hordeum vulgare L.) as a potential source of antioxidants. Cereal Chemistry 89(6):290-295. https://doi.org/10.1094/cchem-03-12-0029-r

Gordeeva, E. I., Shoeva, O. Yu., Yudina, R. S., Kukoeva, T. V., and Khlestkina, E.K. 2018. Effect of seed pre-sowing gamma-irradiation treatment in bread wheat lines differing by anthocyanin pigmentation. Cereal Research Communications 46(1):41-53. https://doi. org/10.1556/0806.45.2017.059

Gordeeva, E. I., Glagoleva, A. Yu., Kukoeva, T.V., Khlestkina, E. K., and Shoeva, O. Yu. 2019. Purple-grained barley (Hordeum vulgare L.): marker-assisted development of NILs for investigating peculiarities of the anthocyanin biosynthesis regulatory network. BMC Plant Biology 19 (Suppl 1):52. https://doi.org/10.1186/s12870-019-1638-9

Gotti, R., Amadesi, E., Fiori, J., Bosi, S., Bregola, V., Marotti, I., and Dinelli, G. 2018. Differentiation of modern and an- 
cient varieties of common wheat by quantitative capillary electrophoretic profile of phenolic acids. Journal of Chromatography 1532(1):208-215. https://doi.org/10.1016/j. chroma.2017.11.058

Graziano, S., Marando, S., Prandi, B., Boukid, F., Marmiroli, N., Francia, E., Pecchioni, N., Sforza, S., Visioli, G., and Gulli, M. 2019. Technological quality and nutritional value of two durum wheat varieties depend on both genetic and environmental factors. Journal of Agricultural and Food Chemistry 67(8):2384-2395. https://doi. org/10.1021/acs.jafc.8b06621

Guo, W. and Beta, T. 2013. Phenolic acid composition and antioxidant potential of insoluble and soluble dietary fibre extracts derived from select whole-grain cereals. Food Research International 51(2):518-525. https://doi. org/10.1016/j.foodres.2013.01.008

Gupta, C. and Prakash, D. 2015. Nutraceuticals for geriatrics. Journal of Traditional and Complementary Medicine 5:514. https://doi.org/10.1016/j.jtcme.2014.10.004

Hajji, T., Mansouri, S., Vecino-Bello, X., Cruz-Freire, J. M., Rezgui, S., and Frchichi, A. 2018. Identification and characterization of phenolic compounds extracted from barley husks by LC-MS and antioxidant activity in vitro. Journal of Cereal Science 81(5):83-90. https://doi. org/10.1016/j.jcs.2018.03.008

Halliwell, B. 2007. Biochemistry of oxidative stress. Biochemical Society Transactions 35(5):1147-1150. https://doi. org/10.1042/BST0351147

Hejtmánková, K., Lachman, J., Hejtmánková, A., Pivec, V., and Janovská, D. 2010. Tocols of selected spring wheat (Triticum aestivum L.), einkorn wheat (Triticum monococcum L.) and wild emmer (Triticum dicoccum Schuebl. [Schrank]) varieties. Food Chemistry 123(4):1267-1274. https://doi. org/10.1016/j.foodchem.2010.05.064

Heimler, D., Vignolini, P., Isolani, L., Arfaioli, P., Ghiselli, L., and Romani, A. 2010. Polyphenol content of modern and old varieties of Triticum aestivum L. and T. durum Desf. grains in two years of production. Journal of Agricultural and Food Chemistry 58(12):7329-7334. https://doi. org/10.1021/jf1010534

Helnas, A., Kyrø, C., Andersen, I., Lacoppidan, S., Overvad, K., Christensen, J., Tjønneland, A., and Olsen, A. 2016. Intake of whole grains is associated with lower risk of myocardial infarction: the Danish Diet, Cancer and Health Cohort. American Journal of Clinical Nutrition 103:999-1007. https://doi.org/10.3945/ajcn.115.124271

Hidalgo, A. and Brandolini, A. 2017. Nitrogen fertilisation effects on technological parameters and carotenoid, tocol and phenolic acid content of einkorn (Triticum monococcum L. subsp. monococcum): A two-year evaluation. Journal of Cereal Science 73:18-24. https://doi.org/10.1016/j. jcs.2016.11.002

Hidalgo, A., Brandolini, A., and Ratti, S. Influence of genetic and environmental factors on selected nutritional traits of Triticum monococcum. Journal of Agricultural and Food Chemistry 57(14):6342-6348. https://doi.org/10.1021/jf901180q

Hithamani, G. and Srinivasan, K. 2014. Bioaccessibility of polyphenols from wheat (Triticum aestivum), sorghum (Sorghum bicolor), green gram (Vigna radiata), and chickpea (Cicer arietinum) as influenced by domestic food processing. Journal of Agricultural and Food Chemistry 62(46):11170-11179. https://doi.org/10.1021/jf503450u

Holtekjølen, A. K., Kinitz, C., and Knutsen, S. H. 2006. Flavanol and Bound Phenolic Acid Contents in Different Barley Varieties. Journal of Agricultural and Food Chemistry 54(6):2253-2260. https://doi.org/10.1021/jf052394p

Hosseinian, F. S. and Mazza, G. 2009. Triticale bran and straw: Potential new sources of phenolic acids, proanthocyani- dins, and lignans. Journal of Functional Foods 1(1):57-64. https://doi.org/10.1016/j.jff.2008.09.009

Hurtado-Fernández, E., Gómez-Romero, M., Carrasco-Pancorbo, A., and Fernández-Gutiérrez, A. 2010. Application and potential of capillary electroseparation methods to determine antioxidant phenolic compounds from plant food material. Journal of Pharmaceutical and Biomedical Analysis 53(5):1130-1160. https://doi.org/10.1016/j. jpba.2010.07.028

Hussain, A., Larsson, H., Olsson, M. E., Kuktaite, R., Grausgruber, H., and Johansson, E. 2012. Is organically produced wheat a source of tocopherols and tocotrienols for health food? Food Chemistry 132(4):1789-1795. https:// doi.org/10.1016/j.foodchem.2011.11.141

Idehen, E., Tang, Y., and Sang, S. 2017. Bioactive phytochemicals in barley. Journal of Food and Drug Analysis 25:148161. https://doi.org/10.1016/j.jfda.2016.08.002

Khlestkina, E. K., Usenko, N.I., Gordeeva, E.I., Stabrovskaya, O. I., Sharfunova, I. B., and Otmakhova Yu. S. 2017. Marker-controlled production of wheat forms with elevated levels of bioflavonoids: product evaluation to justify the importance of the direction. Vavilovskii zhurnal genetiki i selektsii 21(5):545-553. https://doi.org/10.18699/ VJ17.25-o (In Russian)

Koenig, R. T., Dickman, J. R., Wise, M. L., and Ji, L. L. 2011. Avenanthramides are bioavailable and accumulate in hepatic, cardiac, and skeletal muscle tissue following oral gavage in rats. Journal of Agricultural and Food Chemistry 59(12):6438-6443. https://doi.org/10.1021/jf2002427

Konarev, A. V. 1994. All-Russian Institute of Crop Science and it contribution to the development of agricultural science and breeding of the country. Agricultural Biology 3:13-75. (In Russian)

Konarev, A. V. and Khoreva, V.I. 2000. Biochemical research of plant genetic resources in VIR. VIR, S-Petersburg, Russia. (In Russian)

Konarev, A. V., Loskutov, I. G., Shelenga, T. V., Khoreva, V. I., and Konarev, Al.V. 2019. Plant genetic resources (PGR) - an endless source of healthy food. Agragnaya Rossia 2:38-48. https://doi.org/10.30906/1999-56362019-2-38-48 (In Russian)

Kouřimská, I. L., Sabolová, M., Horčička, P., Rys S., and Božik, M. 2018. Lipid content, fatty acid profile, and nutritional value of new oat cultivars. Journal of Cereal Science 84(11):44-48. https://doi.org/10.1016/j.jcs.2018.09.012

Lachman, J., Hejtmánková, K., and Kotíková, Z. 2013. Tocols and carotenoids of einkorn, emmer and spring wheat varieties: Selection for breeding and production. Journal of Cereal Science 57(2):207-214. https://doi.org/10.1016/j. jcs.2012.05.011

Lachman, J., Hejtmánková, A., Orsák, M., Popov, M., and Martinek, P. 2018. Tocotrienols and tocopherols in colored-grain wheat, tritordeum and barley. Food Chemistry 240(2):725-735. https://doi.org/10.1016/j.foodchem.2017.07.123

Lee, C., Han, D., Kim, B., Baek, N., and Baik, B. K. 2013. Antioxidant and anti-hypertensive activity of anthocyaninrich extracts from hulless pigmented barley cultivars. International Journal of Food Science and Technology 48(5):984-991. https://doi.org/10.1111/ijfs.12050

Leonova, S., Gnutikov, A., Loskutov, I., Blinova, E., Gustafsson, K.-E., and Olsson, O. 2020. Diversity of avenanthramides content in wild and cultivated oat. Proceedings on Applied Botany, Genetics and Breeding. (In press).

Li, W., Friel, J., and Beta, T. 2010. An evaluation of the antioxidant properties and aroma quality of infant cereals. Food Chemistry 121(4):1095-1102. https://doi.org/10.1016/j. foodchem.2010.01.056 
Li, M., Koecher, K., Hansen, L., and Ferruzzi, M. G. 2017. Phenolics from whole grain oat products as modifiers of starch digestion and intestinal glucose transport. Journal of Agricultural and Food Chemistry 65(32):6831-6839. https://doi.org/10.1021/acs.jafc.7b02171

Li, X. P., Li, M. Y., Ling, A. J., Hu, X. Z., Ma, Z., Liu, L., and Li, Y.X. 2017. Effects of genotype and environment on avenanthramides and antioxidant activity of oats grown in northwestern China. Journal of Cereal Science 73(1):130137. https://doi.org/10.1016/j.jcs.2016.12.005

Lin, S., Guo, H., Duo, J., Gong, B., Lu, Y., Wang, L., Zhang, Q., Qin, W., and Wu, D. T. 2018. Phenolic profiles, $\beta$-glucan contents, and antioxidant capacities of colored Qingke (Tibetan hulless barley) cultivars. Journal of Cereal Science 81(5):69-75. https://doi.org/10.1016/j.jcs.2018.04.001

Liu, R. H. 2007. Whole grain phytochemicals and health. Journal of Cereal Science 46(3):207-219. https://doi. org/10.1016/j.jcs.2007.06.010

Liu, Y. 2010. Beta-glucan effects on pasting properties and potential health benefits of flours from different oat lines. Graduate Theses and Dissertations. Paper 11303. Ames, lowa: lowa State University.

Liu, H., Bruce, D. R., Sissons, M., Able, A. J., and Able, J. A. 2018. Genotype-dependent changes in the phenolic content of durum under water-deficit stress. Cereal Chemistry 95(1):59-78. https://doi.org/10.1002/cche.10007

Liyana-Pathirana, C., Dexter, J., and Shahidi, F. 2006. Antioxidant properties of wheat as affected by pearling. Journal of Agricultural and Food Chemistry 54(17):6177-6184. https://doi.org/10.1021/jf060664d

Lopez-Martinez, L.X., Oliart-Ros, R. M., Valerio-Alfaro, G., Lee, C. H., Parkin, K. L., and Garcia, H. S. 2009. Antioxidant activity, phenolic compounds and anthocyanins content of eighteen strains of Mexican maize. LWT Food Science and Technology 42(6):1187-1192. https://doi. org/10.1016/j.Iwt.2008.10.010

Loskutov, I. G. 1999. N. I. Vavilov and his Institute. A history of the world collection of plant genetic resources in Russia. FAO /IPGRI, Rome.

Loskutov, I. G. 2007. Oat (Avena L.). Diversity, taxonomy, evolution and breeding value. SPb: GNTs RF VIR. (In Rissian)

Loskutov, I. G. 2009. The history of plant genetic resources in Russia. SPb, GNTs RF VIR. (In Rissian)

Loskutov, I. G. and Polonskiy, V. I. 2017. Content of $\beta$-glucans in oat grain as a perspective direction of breeding for health products and fodder. Agricultural biology 52(4):646-657. https://doi.org/10.15389/agrobiology.2017.4.646rus (In Rissian)

Loskutov, I. G. and Rines H. W. 2011. Avena L. Ed. C. Kole. Wild Crop Relatives: Genomic and Breeding Resources. Cereals. Heidelberg, Berlin, New York: Springer-Verlag, 1:109184. https://doi.org/10.1007/978-3-642-14228-4_1

Loskutov, I. G., Shelenga, T. V., Konarev, A. V., Shavarda, A. L., Blinova, E. V., and Dzyubenko, N. I. 2017. The metabolomic approach to the comparative analysis of wild and cultivated species of oats (Avena L.). Russian Journal of Genetics: Applied Research 7(5):501-508. https://doi. org/10.1134/S2079059717050136

Loskutov, I. G., Shelenga, T. V., Konarev, A. V., Horeva, V.I., Shavarda, A. L., Blinova, E. V., and Gnutikov, A. A. 2019a. Biochemical aspects of interactions between fungi and plants: a case study of Fusarium in oats. Agricultural biology 54(3):575-588. https://doi.org/10.15389/ agrobiology.2019.3.575eng (In Rissian)

Loskutov, I. G., Shelenga, T. V., Konarev, A. V., Vargach, Yu. I., Porokhovinova, E. A., Blinova, E. V., Gnutikov, A. A., and Rodionov, A. V. 2019a. Modern approach of structuring the variety diversity of the naked and covered forms of cultivated oats (Avena sativa L.). Ekologicheskaya genetika (In Russian, in press).

Luithui, Y., Nisha, R. B., and Meera, M. S. 2019. Cereal by-products as an important functional ingredient: effect of processing. Journal of Food Science and Technology 56(1):111. https://doi.org/10.1080/09637480601093236

Luthria, D. L., Yingjian, L., and Mariajohn, K. M. 2015. Bioactive phytochemicals in wheat: Extraction, analysis, processing, and functional properties. Journal of Functional Foods 18(10):910-925. https://doi.org/10.1016/j. jff.2015.01.001

Madhujith, T., Izydorczyk, M., and Shahidi, F. 2006. Antioxidant properties of pearled barley fractions. Journal of Agricultural and Food Chemistry 54(9):3283-3289. https:// doi.org/10.1021/jf0527504

Mareček, V., Mikyška, A., Hampel, D., Čejka, P., Neuwirthová, J., Malachová, A., and Cerkal, R. 2017. ABTS and DPPH methods as a tool for studying antioxidant capacity of spring barley and malt. Journal of Cereal Science 73(1):4045. https://doi.org/10.1016/j.jcs.2016.11.004

Martínez-Tomé, M., Murcia, M. A., Frega, N., Ruggieri, S., Jiménez, A. M., Roses, F., and Parras, P. 2004. Evaluation of antioxidant capacity of cereal brans. Journal of Agricultural and Food Chemistry 52(15):4690-4699. https://doi. org/10.1021/jf049621

Martinez-Villaluenga, C. and Penas, E. 2017. Health benefits of oat: current evidence and molecular mechanisms. Current Opinion in Food Science 14:26-31. https://doi. org/10.1016/j.cofs.2017.01.004

Martínez, M., Motilva, M.J., Hazas, M-C. L., Romero, M.P., Vaculova, K., and Ludwig, I.A. 2018. Phytochemical composition and $\beta$-glucan content of barley genotypes from two different geographic origins for human health food production. Food Chemistry 245:61-70. https://doi. org/10.1016/j.foodchem.2017.09.026

Martinia, D., Taddei, F., Ciccoritti, R., Pasquini, M., Nicoletti, I., Corradini, D., and D'Egidio, M. G. 2015. Variation of total antioxidant activity and of phenolic acid, total phenolics and yellow coloured pigments in durum wheat (Triticum turgidum L. var. durum) as a function of genotype, crop year and growing area. Journal of Cereal Science 65:175185. https://doi.org/10.1016/j.jcs.2015.06.012

Masisi, K., Diehl-Jones, W. L., Gordon, J., Chapman, D., Moghadasian, M. H., and Beta, T. 2015. Carotenoids of aleurone, germ, and endosperm fractions of barley, corn and wheat differentially inhibit oxidative stress. Journal of Agricultural and Food Chemistry 63(10):2715-2724. https://doi.org/10.1021/jf5058606

Masisi, K., Beta, T., and Moghadasian, M. H. 2016. Antioxidant properties of diverse cereal grains: A review on in vitro and in vivo studies. Food Chemistry 196:90-97. https:// doi.org/10.1016/j.foodchem.2015.09.021

Mattila, P., Pihlava, J., and Hellström, J. 2005. Contents of phenolic acids, alkyl- and alkenylresorcinols, and avenanthramides in commercial grain products. Journal of Agricultural and Food Chemistry 53(21):8290-8295. https://doi. org/10.1021/jf051437z

Mazewski, C., Liang, K., and de Mejia, E. G. 2017. Inhibitory potential of anthocyanin-rich purple and red corn extracts on human colorectal cancer cell proliferation in vitro. Journal of Functional Foods 34(7):254-265. https:// doi.org/10.1016/j.jff.2017.04.038

Menga, V., Fares, C., Troccoli, A., Cattivelli, L., and Baiano, A. 2010. Effects of genotype, location and baking on the phenolic content and some antioxidant properties of cereal species. International Journal of Food Science and Technology 45(1):7-16. https://doi.org/10.1111/j.13652621.2009.02072.x 
Mishra, L. K., Sarkar, D., Zwinger, S., and Shetty, K. 2017. Phenolic antioxidant-linked anti-hyperglycemic properties of rye cultivars grown under conventional and organic production systems. Journal of Cereal Science 76(7):108115. https://doi.org/10.1016/j.jcs.2017.06.002

Miyazawa, T., Nakagawa, K., and Sookwong, P. 2011. Health benefits of vitamin $E$ in grains, cereals and green vegetables. Trends in Food Science and Technology 22(12):651654. https://doi.org/10.1016/j.tifs.2011.07.004

Montilla, E. C., Hillebrand, S., Antezana, A., and Winterhalter, P. 2011. Soluble and bound phenolic compounds in different bolivian purple corn (Zea mays L.) cultivars. Journal of Agricultural and Food Chemistry 59(13):70687074. https://doi.org/10.1021/jf201061x

Mpofu, A., Sapirstein, H.D., and Beta, T. 2006. Genotype and environmental variation in phenolic content, phenolic acid composition, and antioxidant activity of hard spring wheat. Journal of Agricultural and Food Chemistry 54(4):1265-1270. https://doi.org/10.1021/jf052683d

Multari, S., Pihlava, J.-M., Ollennu-Chuasam, P., Hietaniemi, V., Yang, B., and Suomela, J.-P. 2018. Identification and quantification of avenanthramides and free and bound phenolic acids in eight cultivars of husked oat (Avena sativa L.) from Finland. Journal of Agricultural and Food Chemistry 66(11):2900-2908. https://doi.org/10.1021/ acs.jafc. $7 \mathrm{~b} 05726$

Ndolo, V. U., Beta, T., and Fulcher, R. G. 2013. Ferulic acid fluorescence intensity profiles and concentration measured by HPLC in pigmented and non-pigmented cereals. Food Research International 52(1):109-118. https://doi. org/10.1016/j.foodres.2013.02.031

Nicoletti, I., Martini, D., De Rossi, A., Taddei, F., D'Egidio, M. G., and Corradini, D. 2013. Identification and quantification of soluble free, soluble conjugated, and insoluble bound phenolic acids in durum wheat (Triticum turgidum L. var. durum) and derived products by RP-HPLC on a semimicro separation scale. Journal of Agricultural and Food Chemistry 61(48):11800-11807. https://doi.org/10.1021/jf403568c

Patel, S. 2015. Cereal bran fortified-functional foods for obesity and diabetes management: Triumphs, hurdles and possibilities. Journal of Functional Foods 14(14):255-269. https://doi.org/10.1016/j.jff.2015.02.010

Paznocht, L., Kotíková, Z., Lachman, J., Orsák, M., Eliášová, M., and Martinek, P. 2018. Free and esterified carotenoids in pigmented wheat, tritordeum and barley grains. Food Chemistry 240(2):670-678. https://doi.org/10.1016/j. foodchem.2017.07.151

Peh, H. Y., Tan, W. S. D., Liao, W., and Wong, W. S. F. 2016. Vitamin E therapy beyond cancer: Tocopherol versus tocotrienol. Pharmacological Therapy 162(1):152-169. https:// doi.org/10.1016/j.pharmthera.2015.12.003

Pihlava, J.-M., Hellström, J., Kurtelius, T., and Mattila, P. 2018. Flavonoids, anthocyanins, phenolamides, benzoxazinoids, lignans and alkylresorcinols in rye (Secale cereale) and some rye products. Journal of Cereal Science 79(1):183-192. https://doi.org/10.1016/j.jcs.2017.09.009

Poloni, D. M., Dangles, O., and Vinson, J. A. 2019. Binding of plant polyphenols to serum albumin and LDL: healthy implications for heart disease. Journal of Agriculture and Food Chemistry 67(33):9139-9147. https://doi. org/10.1021/acs.jafc.8b06674

Polonskiy, V.I., Sumina, A. V., Pavlova, E. V., and Shaldaeva, T. M. 2016a. Variation of the total content of antioxidants in the grain of oats and barley grown in intermountain troughs. Uspekhi sovremennogo estestvoznaniya 8:114-119. (In Russian)

Polonskiy, V.I., Sumina, A. V., Shaldaeva, T.M., and Strupan, E. A. 20166. Evaluation of the content of antioxi- dants in barley and oats in the grain based on its physical indicators. Vestnik Krasnoyaskogo GAU 8:59-64. (In Russian)

Pridal, A. A., Böttger, W., and Ross, A. B. 2018. Analysis of avenanthramides in oat products and estimation of avenanthramide intake in humans. Food Chemistry 253(7):93-100. https://doi.org/10.1016/j.foodchem.2018.01.138

Ragaee, S., Abdel-Aal, E. S. M., and Noaman, M. 2006. Antioxidant activity and nutrient composition of selected cereals for food use. Food Chemistry 98(1):32-38. https://doi. org/10.1016/j.foodchem.2005.04.039

Rosicka-Kaczmarek, J., Komisarczyk, A., and Nebesny, E. 2018. Heteropolysaccharide preparations from rye and wheat bran as sources of antioxidants. Journal of Cereal Science 81(5):37-43. https://doi.org/10.1016/j.jcs.2018.03.013

Ross, A. B., Shepherd, M. J., Schüpphaus, M., Sinclair, V., Alfaro, B., Kamal-Eldin, A., and Åman, P. 2003. Alkylresorcinols in cereals and cereal products. Journal of Agricultural and Food Chemistry 51(14):4111-4118. https://doi. org/10.1021/jf0340456

Sedej, I., Sakač, M., Mandić, A., Mišan, A., Tumbas, V., and Hadnađev, M. 2011. Assessment of antioxidant activity and rheological properties of wheat and buckwheat milling fractions. Journal of Cereal Science 54(3):347-353. https://doi.org/10.1016/j.jcs.2011.07.001

Sen, C. K., Khanna, S., and Roy, S. 2007. Tocotrienols in health and disease: The other half of the natural vitamin $E$ family. Molecular Aspects of Medicine 28(5-6):692-728. https://doi.org/10.1016/j.mam.2007.03.001

Shahidi, F. and Ambigaipalan, P. 2015. Phenolics and polyphenolics in foods, beverages and spices: Antioxidant activity and health effects - A review. Journal of Functional Foods 18:820-897. https://doi.org/10.1016/j. jff.2015.06.018

Shao, Y. and Bao, J. 2015. Polyphenols in whole rice grain: Genetic diversity and health benefits. Food Chemistry 180(8):86-97. https://doi.org/10.1016/j.foodchem.2015.02.027

Shao, Y., Hu, Z., Yu, Y., Mou, R., Zhu, Z., and Beta, T. 2018. Phenolic acids, anthocyanins, proanthocyanidins, antioxidant activity, minerals and their correlations in non-pigmented, red, and black rice. Food Chemistry 239(1):733741. https://doi.org/10.1016/j.foodchem.2017.07.009

Shebis, Y., Iluz, D., Kinel-Tahan, Y., Dubinsky, Z., and Yehoshua, Y. 2013. Natural antioxidants: function and sources. Food and Nutrition Sciences 4:643-649. https://doi. org/10.4236/fns.2013.46083

Shewry, P. R. and Hey, S. 2015. Do "ancient" wheat species differ from modern bread wheat in their contents of bioactive components? Journal of Cereal Science 65:236-243. https://doi.org/10.1016/j.jcs.2015.07.014

Shewry, P. R., Piironen, V., Lampi, A. M., Nyström, L., Li, L., Rakszegi, M., Fraś, A., Boros, D., Gebruers, K., Courtin, C. M., Delcour, J. A., Andersson, A. A. M., Dimberg, L., Bedő, Z., and Ward, J. L. 2008. Phytochemical and fiber components in oat varieties in the HEALTHGRAIN diversity screen. Journal of Agricultural and Food Chemistry 56(21):9777-9784. https://doi.org/10.1021/jf801880d

Shi, Y., O'Shea, J. M., and Chu, Y.-F. 2014. The bioavailability and metabolism of phenolics, a class of antioxidants found in grains. Cereal Foods World 59(2):52-58. https:// doi.org/10.1094/CFW-59-2-0052

Shoeva, O.Y., Gordeeva, E.I., Arbuzova, V.S., and Khlestkina, E. K. 2017. Anthocyanins participate in protection of wheat seedlings from osmotic stress: a case study of near isogenic lines. Cereal Research Communications 45(1):47-56. https://doi.org/10.1556/0806.44.2016.044 
Shoeva, O. Yu. and Khlestkina, E. K. 2018. Anthocyanins participate in the protection of wheat seedlings against cadmium stress. Cereal Research Communications 46(2):242252. https://doi.org/10.1556/0806.45.2017.070

Shoeva, O. Yu., Strygina, K. V., and Khlestkina, E. K. 2018. Genes controlling systesis of flavinoids and melanins pigments in barley. Vavilovaskii zhurnal genetiki i selektsii 22(3):333-342. https://doi.org/10.18699/VJ18.369 (In Russian)

Siebenhandl, S., Grausgruber, H., Pellegrini, N., Rio, D. D., Fogliano, V., Pernice, R., and Berghofer, E. 2007. Phytochemical profile of main antioxidants in different fractions of purple and blue wheat, and black barley. Journal of Agricultural and Food Chemistry 55(21):8541-8547. https://doi.org/10.1021/jf072021

Skulachev, M. V. and Skulachev, M. B. 2017. Proof of mammalian aging and perspectives of a biochemical approach in the fight against old age. Biokhimiya 82(12):1747-1770. https://doi.org/10.1134/S000629791712001X (In Russian)

Sovrani, V., Blandino, M., Scarpino, V., Reyneri, A., Copsson, J. D., Travaglia, F., Locatelli, M., Bordiga, M., Montella, R., and Arlorio, M. 2012. Bioactive compound content, antioxidant activity, deoxynivalenol and heavy metal contamination of pearled wheat fractions. Food Chemistry 135:39-46. https://doi.org/10.1016/j.foodchem.2012.04.045

Strygina, K. V., Börner, A., and Khlestkina, E. K. 2017. Identification and characterization of regulatory network components for anthocyanin synthesis in barley aleurone. BMC Plant Biology 17 (Suppl 1):184. https://doi.org/10.1186/ s12870-017-1122-3

Strygina, K. V. and Khlestkina, E. K. 2019. Myc-like transcriptional factors in wheat: Structural and functional organization of the subfamily I members. BMC Plant Biology 19 (Suppl 1):50. https://doi.org/10.1186/s12870-019-1639-8

Strygina, K. V. and Khlestkina, E. K. 2019. Structural and functional divergence of the Mpc1 genes in wheat and barley. BMC Evolutionary Biology 19 (Suppl 1):45. https://doi. org/10.1186/s12862-019-1378-3

Suchecka, D., Harasym, J.P., Wilczak, J., Gajewska, M., Oczkowski, M., Gudej, S., Błaszczyk, K., Kamola, D., Filip, R., and Gromadzka-Ostrowska, J. 2015. Antioxidative and anti-inflammatory effects of high beta-glucan concentration purified aqueous extract from oat in experimental model of LPS-induced chronic enteritis. Journal of Functional Foods 14(4):244-254. https://doi.org/10.1016/j. jff.2014.12.019

Thomas, M., Kim, S., Guo, W., Collins, F. W., Wise, M. L., and Meydani, M. 2018. High levels of avenanthramides in oat-based diet further suppress high fat diet-induced atherosclerosis in Ldlr-/- mice. Journal of Agricultural and Food Chemistry 66(2):498-504. https://doi.org/10.1021/ acs.jafc. $7 \mathrm{~b} 04860$

Trehan, S., Singh, N., and Kaur, A. 2018. Characteristics of white, yellow, purple corn accessions: phenolic profile, textural, rheological properties and muffin making potential. Journal of Food Science and Technology 55(6):23342343. https://doi.org/10.1007/s13197-018-3171-5

Tucakovic, L., Colson, N., and Singh, I. 2015. Relationship between common dietary polyphenols and obesityinduced inflammation. Food Public Health 5(3):84-91. https://doi.org/10.5923/j.fph.20150503.04

Tufan, A. N., Çelik, S. E., Özyürek, M., Güçlü, K., and Apak, R. 2013. Direct measurement of total antioxidant capacity of cereals: QUENCHER-CUPRAC method. Talanta 108(4):136-142. https://doi.org/10.1016/j.talanta.2013.02.061
Usenko, N. I., Khlestkina, E. K., Asavasanti, S., Gordeeva, E. I., Yudina, R. S., and Otmakhova, Y. S. 2018. Possibilities of enriching food products with anthocyanins by using new forms of cereals. Foods and Raw Materials 6(1):128-135. https://doi.org/10.21603/2308-4057-2018-1-128-135

Vargach, Yu. I., Mertvisheva, M. E., and Loskutov, I. G. 2016. Antioxidant activity of kernel and hulls of oat. Plodovodstvo i yagodovodstvo Rossii 47:57-61. (In Russian)

Wang, Y. and Frei, M. 2011. Stressed food - the impact of abiotic environmental stresses on crop quality. Agriculture Ecosystems and Environment 141:271-286. https:// doi.org/10.1016/j.agee.2011.03.017

Wu, W., Tang, Y., Yang, J., Idehen, E., and Sang, S. 2018. Avenanthramide aglycones and glucosides in oat bran: chemical profile, levels in commercial oat products, and cytotoxicity to human colon cancer cells. Journal of Agricultural and Food Chemistry 66(30):8005-8014. https:// doi.org/10.1021/acs.jafc.8b02767

Xu, F., Bao, J., Kim, T.-S., and Park, Y.-J. 2016. Genome-wide association mapping of polyphenol contents and antioxidant capacity in whole-grain rice. Journal of Agricultural and Food Chemistry 64(22):4695-4703. https://doi. org/10.1021/acs.jafc.6b01289

Yao, Y., Sang, W., Zhou, M., and Ren, G. 2010. Antioxidant and a-glucosidase inhibitory activity of colored grains in China. Journal of Agricultural and Food Chemistry 58(2):770774. https://doi.org/10.1021/jf903234c

Yashin, A. Ya. 2008. Injection-flow system with amperometric detector for the selective determination of antioxidants in food and beverages. Rossiiskii khimicheskii zhurnal 52(2):130-135. (In Russian)

Yashin, A. Ya., Yashin, Ya. N., Fedina, P.A., and Chernousova, N. I. 2012. Determination of natural antioxidants in food grains and legumes. Analitika 2(1):32-36. (In Russian)

Yoshida, A., Sonoda, K., Nogata, Y., Nagamine, T., Sato, M., Oki, T., Hashimoto, S., and Ohta, H. 2010. Determination of free and bound phenolic acids, and evaluation of antioxidant activities and total polyphenolic contents in selected pearled barley. Food Science and Technology Research 16(3):215-224. https://doi.org/10.3136/ fstr.16.215

Zavala-Lopez, M., Lopez-Tavera, E., Figueroa-Cardenas, J. D., Serna-Saldívar, S. O., and García-Lara, S. 2018. Screening of major phenolics and antioxidant activities in teosinte populations and modern maize types. Journal of Cereal Science 79:276-285. https://doi.org/10.1016/j. jcs.2017.11.007

Zaupa, M., Scazzina, F., Dall'Asta, M., Calani, L., Del Rio, D., Bianchi, M. A., Melegari, C., De Albertis, P., Tribuzio, G., Pellegrini, N., and Brighenti, F. 2014. In vitro bioaccessibility of phenolics and vitamins from durum wheat aleurone fractions. Journal of Agricultural and Food Chemistry 62(7):1543-1549. https://doi.org/10.1021/jf404522a

Zduńczyk, Z., Flis, M., Zieliński, H., Wróblewska, M., Antoszkiewicz, Z., and Juśkiewicz, J. 2006. In vitro antioxidant activities of barley, husked oat, naked oat, triticale, and buckwheat wastes and their influence on the growth and biomarkers of antioxidant status in rats. Journal of Agricultural and Food Chemistry 54(12):4168-4175. https:// doi.org/10.1021/jf060224m

Zhou, K., Laux, J.J., and Yu, L. 2004. Comparison of swiss red wheat grain and fractions for their antioxidant properties. Journal of Agricultural and Food Chemistry 52(5):1118-1123. https://doi.org/10.1021/jf030640w

Zhu, Y., Li, T., Fu, X., Abbasi, A. M., Zheng, B., and Liu, R. H. 2015. Phenolics content, antioxidant and antiproliferative activities of dehulled highland barley (Hordeum 
vulgare L.). Journal of Functional Foods 19(12):439-450. https://doi.org/10.1016/j.jff.2015.09.053

Ziegler, J. U., Schweiggert, R. M., Würschum, T., Longin, C. F. H., and Carle, R. 2016. Lipophilic antioxidants in wheat (Triticum spp.): A target for breeding new varieties for future functional cereal products. Journal of Functional Foods 20(1):594-605. https://doi.org/10.1016/j.jff.2015.11.022

Zieliński, H., Ceglińska, A., and Michalska, A. 2007. Antioxidant contents and properties as quality indices of rye cultivars. Food Chemistry 104(3):980-988. https://doi. org/10.1016/j.foodchem.2007.01.002

Zieliński, H. and Kozłowska, H. 2000. Antioxidant activity and total phenolics in selected cereal grains and their different morphological fractions. Journal of Agricultural and Food Chemistry 48(6):2008-2016. https://doi. org/10.1021/jf990619o
Žilić, S., Serpen, A., Akıllıoğlu, G., Gökmen, V., and Vančetović, J. 2012. Phenolic compounds, carotenoids, anthocyanins, and antioxidant capacity of colored maize (Zea mays L.) kernels. Journal of Agricultural and Food Chemistry 60(5):1224-1231. https://doi.org/10.1021/jf204367z

Žilić, S., Šukalović, V.H.T., Dodig, D., Maksimović, V., Maksimović, M., and Basić, Z. 2011. Antioxidant activity of small grain cereals caused by phenolics and lipid soluble antioxidants. Journal of Cereal Science 54(3):417-424. https://doi.org/10.1016/j.jcs.2011.08.006

Žilić, S., Dodig, D., Vančetović, J., Grčić, N., Perić, V., Titan, P., and Maksimović, V. 2019. Composition of anthocyanins in colored grains and the relationship of their non-acylated and acylated derivatives. Polish Journal of Food Nutrition Science 69(2):137-146. http://doi.org/10.31883/ pjfns-2019-105100 